\title{
THALLIUM LEVELS AND BIOACCUMULATION IN ENVIRONMENTAL SAMPLES OF NORTHERN CHILE: HUMAN HEALTH RISKS
}

\author{
FABRIZIO QUEIROLO ${ }^{\prime *}$, SUSANA STEGEN ${ }^{1}$, CARLOS CONTRERAS-ORTEGA ${ }^{1}$, PETER OSTAPCZUK ${ }^{2}$, \\ ALESSANDRO QUEIROLO ${ }^{3}$ AND BETTY PAREDES ${ }^{4}$
}

\author{
'Departamento de Química, Universidad Católica del Norte, Av. Angámos 0610, Antofagasta, Chile, \\ ${ }^{2}$ Geschätsbereich Sicherheit and Strahlenschutz, Research Center Jülich, D-52425 Jülich, Germany \\ ${ }^{3}$ Hospital IST Viña del Mar, Errazuriz 673, Viña del Mar, Chile \\ ${ }^{4}$ Departamento de Química, Universidad Nacional de San Agustín, Santa Catalina 117, Arequipa, Perú
}

(Received: April 17, 2009 - Accepted: September 25, 2009)

\begin{abstract}
Thallium (Tl) is a highly toxic heavy metal; however there is an increasing demand for thallium in the high-technology and a lack of information in the literature. On the other hand, under natural conditions, $\mathrm{Tl}$ occurs in large quantities rarely and plays no role in the metabolism of plants or animal. Studies on the presence of $\mathrm{Tl}$ in the vicinity of a copper mining-impacted region in northern Chile were carried out. A number of different types of environmental samples such as crop plants (potato, broad bean and maize), water, algae (Myriophyllum acuaticum, Zannichellia palustris L.) and one plant species (Tessaria absinthioides) growing wildly in the same area, were examined. All of them are exposed to a natural environmental contamination and to the impact of the copper mining activity throughout the region. Thallium concentration in plants exhibits species-dependent preferences. Thus, the enrichment of $\mathrm{Tl}$ in the edible parts of crop species decreases in the following order: potato $>$ broad bean $>$ maize grain. Thallium contents, expressed as dry weight (d.w.), varied from $<0.001$ to $6.8 \mu g^{-1}$ in crop $^{-1}$ plants, from 0.295 to $8.3 \mu \mathrm{gg}^{-1}$ in algae, and between 0.010 and $0.501 \mu \mathrm{gg}^{-1}$ in plant samples $\left(2-10\right.$ times the level normally found in plants, $0.05 \mu \mathrm{gg}^{-1} \mathrm{dry}_{\mathrm{wt}}$. Dissolved Tl concentrations in rivers were found to be 6 to $120 \mathrm{ngL}^{-1}$. In the current study, the risk for adverse health effects derived from ingestion from potatoes was assessed. It shows that there is an important risk for the infantile and adult population at present.
\end{abstract}

Keywords: Thallium; Chile; river pollution; bioaccumulation, human health risks, heavy metal.

\section{INTRODUCTION}

Thallium is widely distributed in the environment in very low concentrations. The average concentration of $\mathrm{Tl}$ is $0.1-1.0 \mu \mathrm{g} / \mathrm{g}$ in the lithosphere, $0.01-0.02 \mu \mathrm{g} / 1^{1 ; 2}$ in seawater, and $0.01-14 \mu \mathrm{g} / 1$ in fresh water ${ }^{7}$. Thallium ores and minerals ( $\left.\mathrm{TlAsS}_{2}, \mathrm{TlAs}_{2} \mathrm{SbS}_{5},(\mathrm{Cu}, \mathrm{Tl}, \mathrm{Ag})_{2} \mathrm{Se}, \mathrm{Tl}_{2} \mathrm{~S} \cdot \mathrm{AsS}_{3}\right)$ are rare. The metal is recovered during processing of sulphides ores of copper, zinc and lead, containing thallium ${ }^{2 ; 5 ; 8}$. Relatively high levels of this metal are also present in manganese nodules ${ }^{9}$. Inorganic $\mathrm{Tl}$ (I) compounds are more stable than Tl(III) compounds in aqueous solution at neutral $\mathrm{pH}$. Thalium cation (I), $\mathrm{Tl}^{+}$, tends to form stable complexes with sulphur- containing compounds ${ }^{2 ; 10}$ and is particularly toxic in its compounds, as for example: sulphate $\left(\mathrm{Tl}_{2} \mathrm{SO}_{4}\right)$, and acetate $\left(\mathrm{CH}_{3} \mathrm{CO}_{2} \mathrm{Tl}\right)$, Carbonates $\left(\mathrm{TL}_{2} \mathrm{CO}_{3}\right)$ and sulphide $\left(\mathrm{Tl}_{2} \mathrm{~S}\right)$, are poorly soluble and less toxic ${ }^{11}$.

Thallium is one of the most toxic metals and causes chronic and acute poisoning ${ }^{6}$. It is more toxic to mammals than $\mathrm{Hg}, \mathrm{Cd}, \mathrm{Pb}, \mathrm{Cu}$ or $\mathrm{Zn}$. Since its discovery in 1861 it is known that Tl have caused many accidental, occupational and therapeutic poisonings in the entire world ${ }^{1,2 ; 3 ; 4 ; 5 ; 6}$. Examples are "thallium poisoning" in Brazil ${ }^{12}$, Mexico ${ }^{13: 14}$ Spain $^{15 ; 16}$, China ${ }^{3 ; 17}$, Belgium ${ }^{18}$, Israel ${ }^{4}$ and USA $^{19}$; "acute thallium poisoning" in Chile ${ }^{20}$, chronic occupational thallium poisoning" in Japan ${ }^{21}$.

Thallium toxicity is related to the interference with some vital potasiumdependence biological reactions, like substitution of potassium in the $\left(\mathrm{Na}^{+} / \mathrm{K}^{+}\right)$ATPase, as well as a high affinity for sulphidryl groups from proteins and other biomolecules ${ }^{5}$. Intoxication of thallium appears after its introduction into the body by inhalation, ingestion via contaminated food and hands, and absorption through skin and mucous membranes. It is distributes widely through the body and accumulates in bones, renal medulla and eventually, in the central nervous system. Neurological symptoms usually appear between 2-5 days after acute exposure cases. Average lethal doses for $\mathrm{Tl}$ in humans its also variable; lethal dose for thallium sulphate has been reported from 8 to $15 \mu \mathrm{g} / \mathrm{g}^{11 ; 23}$. Thallium levels in normal human and animals are $<1 \mu \mathrm{g} / \mathrm{l}$ in blood and urine ${ }^{24},<10 \mu \mathrm{g} /$ $\mathrm{kg}$ in tissues ${ }^{3}$, between $5-10 \mathrm{ng} / \mathrm{g}$ in human hair ${ }^{25},<5 \mathrm{ng} / \mathrm{g}$ in nails, $1-4 \mathrm{ng} / \mathrm{g}$ (w.w.) in kidney, $0.5-5 \mathrm{ng} / \mathrm{g}$ (w.w.) in brain, $0.5-2 \mu \mathrm{g} / \mathrm{L}$ in whole blood and $1 \mu \mathrm{g} /$ day in feces ${ }^{26}$.

Hanzel and Verstraeten ${ }^{42}$ demonstrated that rat $\mathrm{PC} 12$ cells exposure to $\mathrm{Tl}(\mathrm{I})$ or $\mathrm{Tl}(\mathrm{III})$ cations leads to mitochondrial damage and reduced cell viability ${ }^{42}$.

Allus et. a ${ }^{27}$ studied the effect of metals on the grown of plants. Thallium was considerably more toxic than the other elements (e.g. $\mathrm{Cd}, \mathrm{Pb}, \mathrm{Zn}, \mathrm{Fe}$ ) in root and shoot. At water concentration of $2-3 \mu \mathrm{gTl} / \mathrm{ml}$ the activity of photosynthesis in algae is distinctly influenced and at $7 \mu \mathrm{gTl} / \mathrm{ml}$ toxic effects have been observed. The resistance of plants to $\mathrm{Tl}$ in soil and water seems to be specific and not correlated with the ability of thallium accumulation ${ }^{26}$.

The thallium presence in water and aquatic environments has not received much attention due, in part, to difficulties in its low levels measuring and because there is a lack of environmental reference materials having certified values. However, scientists of Canada and China demonstrate that natural sources of elevated $\mathrm{Tl}$ pose a potential health risk to population ${ }^{41}$.

The region of Antofagasta, in the northern part of Chile, worldwide known as the mining capital of the country and one of the most important world's copper producers, is extremely arid. Andes volcanism has always been intense in this region (eruptions, vents, geysers and thermal springs). Rainfall at the Highland takes place from December to March, ranging from 200 to $250 \mathrm{~mm}$ annually ${ }^{28}$. Winter temperature falls to $-30^{\circ} \mathrm{C}$ overnight with daily variations up to $35^{\circ} \mathrm{C}$.

All above makes the natural waters in the Chilean pre-Andes region quite varied, their quality ranging from snow fusion to brine. Saline water predominates and thus its use is highly limited. Sodium, K, Ca, Mg, chlorides, sulphates and nitrates are major components, while $\mathrm{Li}, \mathrm{F}$ and $\mathrm{B}$ are minor ones. Due to the extreme temperature conditions and the high salinity in water, plants habitually grow between December and March. The bulk of produced crop plants are used for self-consumption while part of it is sold at the market.

The aim of the present study was to evaluate the $\mathrm{Tl}$ bioaccumulation in crop plants,-algae and river plants; the $\mathrm{Tl}$ pollution levels in salt rivers and the potential health risks for the population derived from $\mathrm{Tl}$ ingestion. The absence of detailed knowledge of the distribution and dispersion of $\mathrm{Tl}$ in this region is a matter of concern.

\section{RESEARCH AREA}

Sampling was done in the highlands of El Loa province (Fig.1), which is located between $22^{\circ} 12^{\prime}$ and $23^{\circ} 45^{\prime} \mathrm{S}$ and $68^{\circ} 20^{\prime} \mathrm{W}$. The capital of the province is Calama, with approximately 140,000 inhabitants. The Atacameños and Quechua population living in the region amounts about to 4,000 people.

The location of the study has been detailed previusly by Queirolo et. al. ${ }^{29 ; 30 ; 31}$ and by Stegen et al. ${ }^{32 ; 33 ; 34}$. 


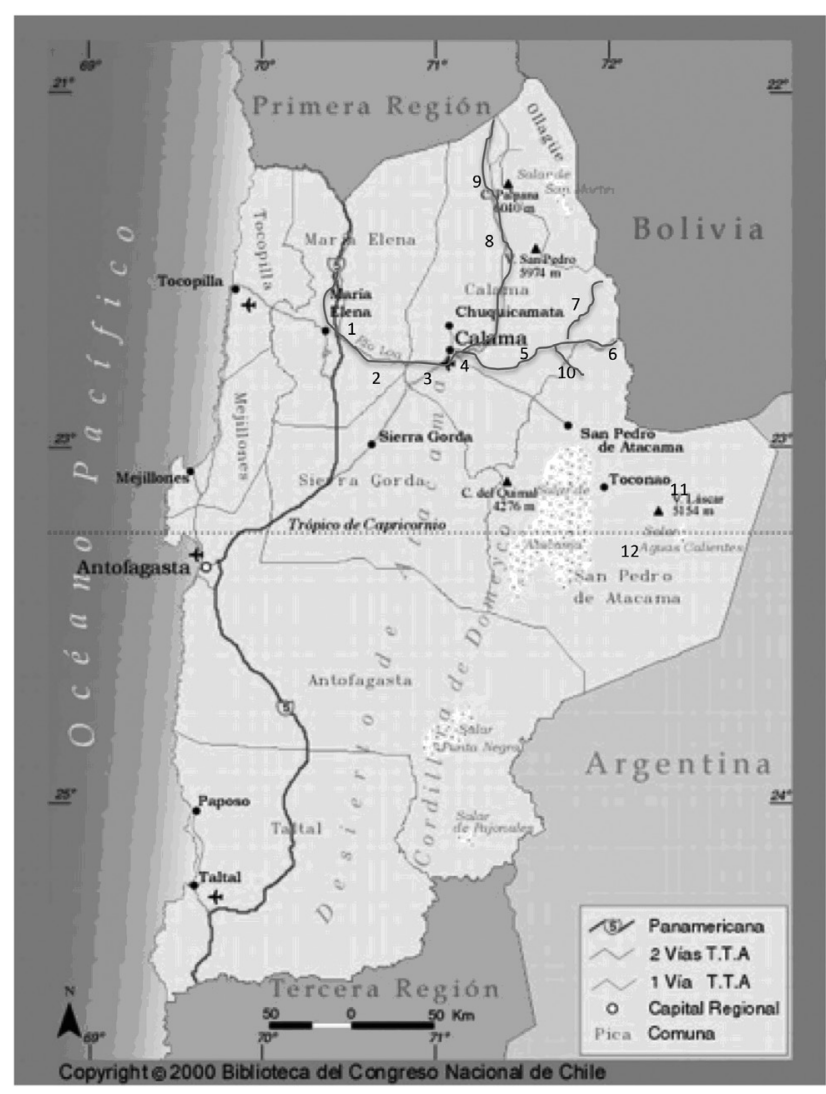

\begin{tabular}{||l|c|}
\hline Name & $\begin{array}{c}\text { Altitude } \\
\text { (m.a.s.I.) }\end{array}$ \\
\hline $\mathbf{1}$ Puente Posada & 1100 \\
\hline 2 Coya Sur & 1170 \\
\hline 3 La Cascada & 2300 \\
\hline 4 Yalquincha & 2300 \\
\hline 5 Yerbas Buenas & 2640 \\
\hline 6 El Tatio & 4250 \\
\hline $\mathbf{7}$ Toconce & 3140 \\
\hline 8 Quinchamale & 3040 \\
\hline 9 Lequena & 3300 \\
\hline 10 Caspana & 3200 \\
\hline 11 Talabre & 3600 \\
\hline 12 Socaire & 3750 \\
\hline
\end{tabular}

Fig.1. Map showing the sampling sites at Rio Loa basin and at Salar de Atacama basin.

\section{Collection sites}

The only permanent surface water is the $440 \mathrm{~km}$ long Loa River which flows to the Pacific Ocean as shown in Fig.1. The Loa River and its main tributaries (Salado and San Salvador) provide water both to the cities and to the mining activity. Furthermore, they support irrigation for limited agricultural and allow the growth of some aquatic plants (algae) and terrestrial flora around the basin. The different sampling sites are shown in Fig. 1 and they are considered representative of the environmental situation of this region.

Water samples were collected at Toconce, Lequena, Quinchamale, Ayquina, Rio Salado, Yalquincha, La Cascada, Coya Sur and Puente Posada. These places are distributed at very different elevations having different streams over them ${ }^{29 ; 30}$. The $\mathrm{pH}$, conductivity, dissolved oxygen and temperature were measured in situ. Water samples were filtered in situ at $0.45 \mu \mathrm{m}$ and acidified wit $\mathrm{HNO}_{3}(1 \% \mathrm{v} / \mathrm{v}$ suprapure grade).

Crop plants sampling was done at Yerbas Buenas (potatoes), Caspana (broad beans), Talabre (broad beans and potatoes) and Socaire (broad beans, maize and potatoes).

The algae species Myriophyllum acuaticum (common name in the North of Chile: Hierba del sapo, Pinito de agua) and Horned pondweed Zannichellia palustris L. (common name in the North of Chile: cachudita de las lagunas) were collected at La Cascada, Yalquincha, Ayquina and in Rio Salado at Yerbas Buenas. They were identified at the National History Museum in Santiago, Chile.

The species Tessaria absinthioides is proposed to evaluate the $\mathrm{Tl}$ bioaccumulation due to its abundance and representativeness. This is a bush with new branches and ash green leaves owing to the many short hairs covering it. It has gemiferous roots and $1-1.5 \mathrm{~m}$ upright stems full of leaves. It frequently grows in the sandy and somewhat humid soils of Bolivia, Chile, Uruguay and Argentina. In Chile it is found from Arica to Lebu. A description of this species was made by Stegen et. al. ${ }^{32}$. The sampling was done at Puente Posada, Coya Sur, Yalquincha and La Cascada.

\section{Sampling and pretreatment}

Samples from several crop species (potato, broad bean, and maize grain) were collected in the field with a random sampling procedure. Each sample consisted of a number of sub-samples taken within an area of $100 \times 100 \mathrm{~m}$ or less. Sampling procedure and sample pretreatment have been discussed previously ${ }^{30}$. Potato and broad bean skin was removed with a quartz knife, since it is sometimes consumed. Water content and the mass correction factor were determined by freeze-drying because water determination by an oven is not recommended for beans and their skin ${ }^{35}$. Water content values were in the $72-79 \%$ range for potatoes, $81-86 \%$ for potato skin (pskin), 78 a $80 \%$ for broad bean, $92-90 \%$ for broad bean skin (bskin) and $75-83 \%$ for maize, depending on the sampling site.

About $5 \mathrm{~kg}$ of the plants (Tessaria absinthioides and the algae Myriophyllum aquaticum and Zannichellia palustris) were taken from each of the sampling sites by applying a random sampling procedure. They were put in polyethylene bags and transported to the laboratory in a cold box in order to avoid alterations during transport. In the laboratory, the particles adhered to the surface of the plant, mainly to the root and the upper and middle parts, were eliminated under a laminar-flow hood by using a quartz knife. The leaves were separated from the stems by hand protected with vinyl gloves. Then, the plant was quickly washes by submerging each part in an alcohol solution at $10 \%\left(\mathrm{CH}_{3} \mathrm{OH} 95 \%\right.$ s.p.) to eliminate the particles adhered on the surface. All samples were frozen at $-20^{\circ} \mathrm{C}$. Due to the handling of the samples in a laboratory environment it was necessary to determine the dry mass correction factor (infrared balance at $\left.105^{\circ} \mathrm{C}\right)^{59}$.

Water samples were collected with sampling bottles (precleaned and rinsed twice with the collected water) generally no deeper than $50 \mathrm{~cm}$. Temperature, $\mathrm{pH}$ and conductivity were recorded. Duplicate samples of 2-L (precleaned polyethylene bottles), previously filtered and acidified, were stored at $4^{\circ} \mathrm{C}$. All samples were placed in polyethylene double bags to protect them from possible dust contamination.

\section{ANALYTICAL PROCEDURES}

For the determination of the total $\mathrm{Tl}$ concentration about $0.3 \mathrm{~g}$ of all solid samples were treated with $2 \mathrm{ml}$ of $\mathrm{HNO}_{3}(65 \%$ suprapure $)$ and $0.5 \mathrm{ml}$ of $\mathrm{HCl}$ (37\% suprapure) in a PMD Kürner microwave oven (5-10 min., power setup 6-8). For samples of high silicate content $0.1 \mathrm{ml}$ of HF were used. After cooling, the solutions were diluted to $25 \mathrm{ml}$ with de-ionized water $(18 \mathrm{M} \Omega)$.

Solutions were analyzed by graphite furnace atomic absorption spectrometry (GF-AAS) (Perkin Elmer Model ANALYST 700 equipped with an HGA-700 graphite furnace and an autosampler). Palladium as matrix modifier, pyrolitic graphite coated graphite tubes, and the method of standard addition were used. Detection limits (LOD) and coefficients of variation $(\mathrm{CV})$ for the different matrices are reported in Table 1. 
Table 1.- Limits of detection (LOD) $)^{\mathrm{a}}$ and coefficients of variation (CV) for the analysis of Thallium performed by graphite furnace atomic absorption spectrometry (GF-AAS)

\begin{tabular}{|c|c|c|c|}
\hline & Plants & Algae & Crop Plants \\
\hline LOD $\left(\mu g^{-1}\right.$ d.w. $)$ & 0.009 & 0.003 & 0.010 \\
\hline CV (\%) & 8.8 & 10 & 2.0 \\
\hline
\end{tabular}

${ }^{a}$ Calculated on the basis of 10 determinations of the blanks as 3 times the standard deviation of the blank

${ }^{b}(\mathrm{CV}) \%$ relative to 10 determinations performed on the same sample.

Thallium was also determined by flame atomic absorption spectrometry (AAS) (Perkin Elmer Model ANALYST 700). LOD for the analysis performed by AAS ( $\mu g g-1$ d.w.) was 0.3 for the crop plants. In surface water samples, Tl was determined by induced coupled plasma - mass spectra (ICP-MS), at the Research Centre of Jülich, Germany.

The accuracy (bias) and precision (\%RSD) of the methods were tested with certified reference materials: Tomato Leaves 1573, Pine Needles 1575 , Citrus Leaves 1572, Bovine Liver 1577, River Sediment 1648 NBS and River Water Reference Material for Trace Metals SLRS-4 NRCC. One sample of reference material and blanks were included in each analytical batch.

Table 2.- Analysis by GF-AAS of certified reference materials: certified values and found values (means \pm SD) and \%RSD.

\begin{tabular}{|c|c|c|c|c|}
\hline SRM & Type & $\begin{array}{c}\text { Certified } \\
\text { values } \\
\text { Tl }\end{array}$ & $\begin{array}{c}\text { Found values } \\
\text { Tl }\end{array}$ & \%RSD \\
\hline 1573 & Tomato Leaves $(\mu \mathrm{g} / \mathrm{g})$ & $(0.05)$ & $0.048 \pm 0.008$ & 16 \\
\hline 1575 & Pine Needles $(\mu \mathrm{g} / \mathrm{g})$ & $(0.05)$ & $0.063 \pm 0.009$ & 14 \\
\hline 1572 & Citrus Leaves $(\mu \mathrm{g} / \mathrm{g})$ & $(<0.01)$ & $<0.01$ & - \\
\hline 1648 & River Sediment $(\mu \mathrm{g} / \mathrm{g})$ & $\begin{array}{c}1.44 \pm \\
0.07\end{array}$ & $1.70 \pm 0.02$ & 1.2 \\
\hline 1577 & Bovine Liver $(\mu \mathrm{g} / \mathrm{g})$ & 0.05 & $0.056 \pm 0.010$ & 18 \\
\hline SLRS-4* & $\begin{array}{c}\text { River Water Reference } \\
\text { Material for Trace } \\
\text { Metals }(\mu \mathrm{g} / \mathrm{L})\end{array}$ & - & $0.008 \pm 0.001$ & 13 \\
\hline
\end{tabular}

*Analyzed by ICP-MS

The results obtained for $\mathrm{Tl}$ are in excellent agreement with the certified values as seen from Table 2 and supported by the traceability test of $t$ Student. The test statistic $t$ was calculated with Eq. (1):

$$
t_{c a l}=\frac{\left(X_{a}-X_{b}\right) \sqrt{n}}{s}
$$

Where $X_{a}=$ duplicated means

$\mathrm{X}_{\mathrm{b}}=$ certified value of Certified Reference Materials (CRM)

$\mathrm{s}=$ standard deviation of $\mathrm{n}$ analysis

The $t_{c a l}$ was compared to the two-sided $t$-value, at a probability of $95 \%$ and $n-1$ degrees of freedom. If the $t_{c a l}<t$-tabulated the accuracy of the applied method is traceable to the CRM.

For external quality control, some of samples were analyzed by ICP-MS, at the Zentralabteilung fuer Chemische Analysen, Abteilung Massenspektrometrie of the Research Centre of Jülich, Germany (Table 3).

Results for the other matrices studied in this work are given in the next section
Table 3.- Tl concentrations (in $\mu \mathrm{gg}^{-1}$ d.w. \pm SD)* in crop plants grown at the pre-Andes northern Chile

\begin{tabular}{|l|c|c|c|c|}
\hline & \multicolumn{4}{|c|}{ Crop plants parts } \\
\hline $\begin{array}{c}\text { Crop } \\
\text { species }\end{array}$ & Flesh & Skin & Flesh** & Skin** \\
\hline (a) Potato & & & & \\
\hline Socaire & $2.1(0.1)$ & $4.5(0.3)$ & $1.8(0.2)$ & $4.3(0.2)$ \\
\hline Talabre & $4.4(0.6)$ & $6.8(0.4)$ & $4.1(0.1)$ & $6.4(0.1)$ \\
\hline $\begin{array}{l}\text { Yerbas } \\
\text { Buenas }\end{array}$ & $3.8(0.2)$ & $5.7(0.6)$ & $3.2(0.2)$ & $5.3(0.3)$ \\
\hline $\begin{array}{l}\text { (b) Broad } \\
\text { bean }\end{array}$ & & & & \\
\hline Socaire & $0.015(0.001)$ & $0.031(0.001)$ & $0.011(0.001)$ & $0.029(0.001)$ \\
\hline Talabre & $0.080(0.001)$ & $0.136(0.010)$ & $0.072(0.001)$ & $0.132(0.002)$ \\
\hline Caspana & $0.006(0.000)$ & $0.022(0.001)$ & $0.005(0.000)$ & $0.019(0.001)$ \\
\hline $\begin{array}{l}\text { (c) Maize } \\
\text { grain }\end{array}$ & & & & \\
\hline Socaire & $<0.010$ & & $0.006(0.000)$ & \\
\hline Talabre & $0.010(0.001)$ & & $0.008(0.000)$ & \\
\hline Caspana & $<0.010$ & & $<0.0001$ & \\
\hline
\end{tabular}

* Mean of three independent determinations.

Coefficients of variation (CV) was always less than $10 \%$

** Analyzed by ICP-MS in the Zentralabteilung für Chemische Analysen, Abteilung Massenspektrometrie at the Research Centre of Jülich, Germany

\section{RESULTS AND DISCUSSION}

Three parallel measurements where made in all cases. The analytical precision, determined by quality assurance and quality control procedures, using duplicates, blanks, internal standards and reference materials, was better than $\pm 10 \%$.

Thalium bioaccumulation in crop species

Results on all the collected samples are summarized in Table 3, as mean values. The enrichment of $\mathrm{Tl}$ in crops is also characterized as species and sites dependant (Fig. 2)

Maize grains (mgrain) contained only traces of $\mathrm{Tl}\left(<0.1 \mathrm{ngg}^{-1}\right)$, since in most cases $\mathrm{Tl}$ concentration was lower than the GF-AAS detection limit. So the contribution of maize to $\mathrm{Tl}$ bioaccumulation via the food chain is expected to be very low in these villages.

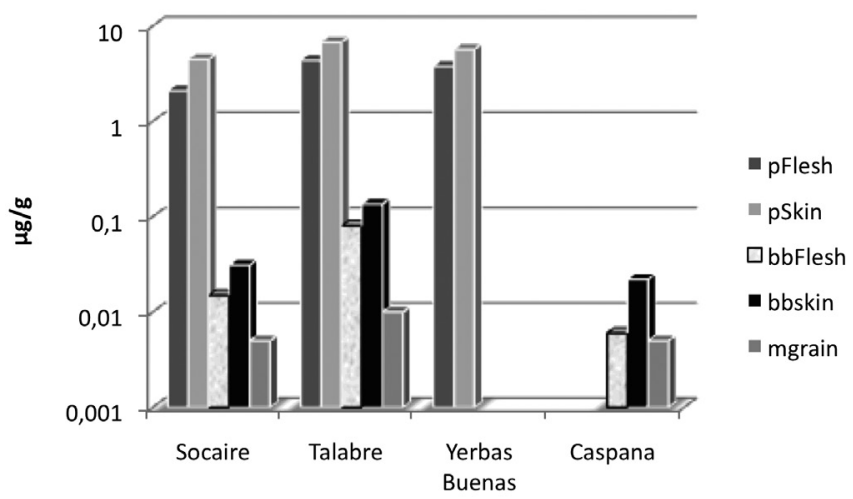

Figure 2.- Concentration distribution of $\mathrm{Tl}$ in crops at the different sampling sites (p:potato, bb: broad beans; m: maize)

Smith and Carson ${ }^{6}$ reported Tl levels in the range of $0.02-0.125{\mu g^{-1}}^{-1}$ for edible plants, from 0.008 to $0.01 \mu \mathrm{gg}^{-1}$ in clover, and from 0.02 to $0.025 \mu \mathrm{gg}^{-1}$ in meadow hay. Broad beans Tl levels (bbskin and bbflesh) determined at this investigation are quite comparable with concentrations at others parts of the world.

Thallium concentrations were found to be very high in potato at Talabre (4.4 $\mu g^{-1}$ in pflesh and $6.8 \mu \mathrm{gg}^{-1}$ in pskin) lower at Yerbas Buenas (3.8 
$\mu \mathrm{gg}^{-1}$ in pflesh and $5.7 \mu \mathrm{gg}^{-1}$ in pskin) and also lower, but still significant, at Socaire $\left(2.1 \mu \mathrm{gg}^{-1}\right.$ in pflesh and $4.5 \mu \mathrm{gg}^{-1}$ in pskin), showing that potatoes are efficient bioaccumulators of this metal. Queirolo et $\mathrm{al}^{30}$ reported that the tendency of $\mathrm{Cd}$ and $\mathrm{Pb}$ in these locations is also to accumulate in the skin of potatoes. Differences of $\mathrm{Tl}$ concentrations in vegetable organs could be due to differences in uptake and/or in differences in translocation within the whole plant. Valuable minerals contained in the potatoes are some of potassium ${ }^{36}$. The explanation for this occurrence would be the behavior of $\mathrm{Tl}^{+}$and $\mathrm{K}^{+}$in soils. Both are univalent ions with similar ionic radii, so thallium is able to interfere with potassium-dependence processes ${ }^{2}$. It seems that soils at Talabre and Yerbas Buenas are extremely polluted by $\mathrm{Tl}$, highly probable related to volcanic activity (Laskar volcano) or to geochemical sources such as thallium minerals ( $\left.\mathrm{TlAsS}_{2}, \mathrm{TlAs}_{2} \mathrm{SbS}_{5},(\mathrm{Cu}, \mathrm{Tl}, \mathrm{Ag})_{2} \mathrm{Se}, \mathrm{Tl}_{2} \mathrm{~S} \cdot \mathrm{AsS}_{3}\right)$, since the soils in this region exhibit a very high natural arsenic content ${ }^{38}$. Inputs from agricultural additives are particularly difficult to detect because the information about them is vague and the $\mathrm{Tl}$ content of pesticides is not well known. Additionally, the link between $\mathrm{Tl}$ and $\mathrm{K}$ may be distorted by the use of potassium fertilizers.

The minimum lethal dose $\left(\mathrm{LD}_{\mathrm{LO}}\right)$ of soluble thallium salts for an adult has been estimated to be $0.7-1.4 \mathrm{~g}$ or $10-20 \mathrm{mg}$ thallium $/ \mathrm{kg}$ for a $70 \mathrm{Kg}$ adult ${ }^{40}$. The Oral Chronic Reference Dose (RfD) for Thallium Carbonate, Thallium Chloride, and Thallium Sulfate is $8.00 \times 10^{-5} \mathrm{mg} / \mathrm{kg}$-day for a $70 \mathrm{Kg}$ adult $\mathrm{t}^{40}$ and $3.7 \times 10^{-4} \mathrm{mg} / \mathrm{kg}$-day for a $15 \mathrm{Kg}$ child ${ }^{40}$. The local villagers in Socaire, Talabre and Yerbas Buenas consume potatoes during the entire year and after air-drying. Table 4 summarizes the criteria assumed in this study to calculate the daily ingestion of $\mathrm{Tl}$ from potatoes (flesh).

Table 4.- Estimation of daily ingestion of $\mathrm{Tl}$ from potatoes consumption (flesh) in different location.

\begin{tabular}{|c|c|c|c|c|c|}
\hline \multirow{3}{*}{$\begin{array}{l}\text { Local } \\
\text { Villagers }\end{array}$} & \multirow{3}{*}{$\begin{array}{c}\begin{array}{c}\mathrm{DW} \\
(\mathrm{mgTl} /\end{array} \\
\mathrm{Kg})\end{array}$} & \multicolumn{2}{|c|}{$\begin{array}{c}\text { Consumption amount } \\
(\mathrm{Kg} / \text { day })\end{array}$} & \multicolumn{2}{|c|}{$\begin{array}{c}\text { Total ingestion mg/ } \\
\text { day }\end{array}$} \\
\hline & & Adult & Children & Adult & hildren \\
\hline & & 0.200 & 0.100 & 0.420 & 0.210 \\
\hline Talabre & 4.4 & 0.200 & 0.100 & 0.880 & 0.440 \\
\hline $\begin{array}{l}\text { Yerbas } \\
\text { Buenas }\end{array}$ & 3.8 & 0.200 & 0.100 & 0.760 & 0.380 \\
\hline
\end{tabular}

The estimated oral daily intake of $\mathrm{Tl}$ from potatoes as well as the risk index for adults (for a body weight of $70 \mathrm{Kg}$ ) and children (for a body weight of 15 $\mathrm{Kg}$ ) are shown in Table 5. This index, known also as hazard quotient (HQ), is a numeric estimate of the systemic toxicity potential posed by a single chemical within a single route of exposure and can quantitative calculated by using the following equation (2):

$$
H Q i=\frac{C D I i}{R f D i}
$$

where: $\mathrm{CDIi}=$ the estimate of chronic daily intake from the exposure assessment

$\mathrm{RfDi}=$ the chronic reference dose for administered or absorbed dose, as appropiate

A quotient under 1 is assumed as safe.

Table 5. Predicted daily exposure to thallium from potatoes (flesh) and hazard quotient.

\begin{tabular}{|l|c|c|c|c|}
\hline \multirow{2}{*}{$\begin{array}{c}\text { Sampling } \\
\text { Site }\end{array}$} & \multicolumn{2}{|c|}{ Adults } & \multicolumn{2}{c|}{ Children } \\
\cline { 2 - 5 } & $\begin{array}{r}\text { Predicted } \begin{array}{c}\text { Exposure* } \\
\text { Quotient** } \\
(\mathrm{mg} / \mathrm{kg} \text {-day) }\end{array} \\
\text { Socaire }\end{array}$ & $\begin{array}{c}\text { Hredicted } \\
\text { Exposure* } \\
\text { Quotient** } \\
(\mathrm{mg} / \mathrm{kg} \text {-day) }\end{array}$ \\
\hline Talabre & $1.3 \times 10^{-3}$ & 75 & $1.4 \times 10^{-2}$ & 175 \\
\hline $\begin{array}{c}\text { Yerbas } \\
\text { Buenas }\end{array}$ & $1.1 \times 10^{-2}$ & 163 & $2.9 \times 10^{-2}$ & 363 \\
\hline
\end{tabular}

* CDIi, based on body weights of $70 \mathrm{Kg}$ for adults and of $15 \mathrm{Kg}$ for children

** Calculated with RfDi values of $8.00 \times 10-5 \mathrm{mg} / \mathrm{kg}$-day for adults $(70 \mathrm{Kg}$ ) and of $3.7 \times 10-4 \mathrm{mg} / \mathrm{kg}$-day for children $(15 \mathrm{Kg})$. HQi $<1$ is assumed as safe

According to above results, mining and volcano activity are important sources of thallium emission into the environment of this region. Thus, the highest hazard quotient is for the village nearest to the active Lascar volcano (Talabre). The current study also shows that the highest risk of adverse health effects comes from the ingestion of potatoes and that there is a significant risk for the infantile and adult population at present.

Thallium bioaccumulation in plants

Thallium concentration in Tessaria absinthioides varies considerably depending on the sampling site and on the analyzed part of the plant. Roots are the best bioaccumulators for thallium as concentration increases from leaves to roots in all sites collected (Fig. 3)

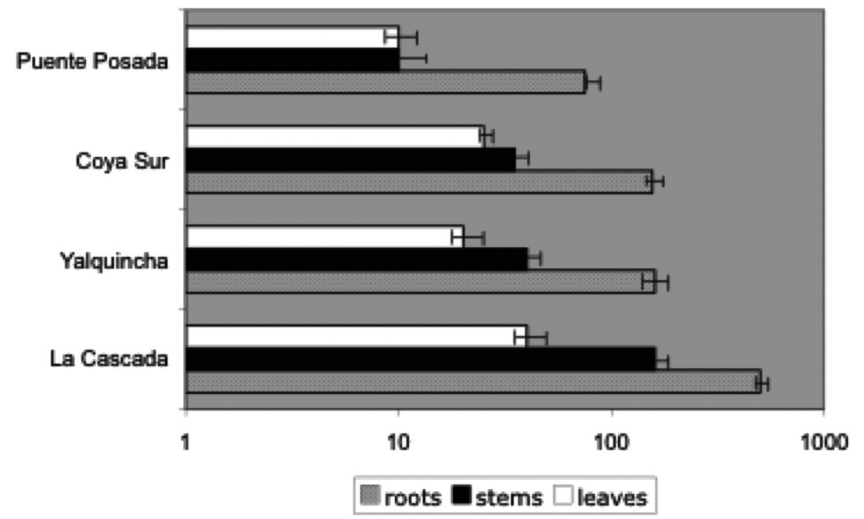

Figure 3.- Thallium levels $\left(\mathrm{ngg}^{-1}\right.$ d.w.) in different parts of Tessaria absinthioides sampled at various sites.

The highest concentration of $\mathrm{Tl}$ was found in all parts of the plants collected at La Cascada were the water is turbid. Upstream of this sampling site, sewage water was observed. Thalium is present in this industrial area, were mean concentration levels of $\mathrm{Tl}$ in water are $120 \mathrm{ngL}^{-1}$ (Table 7), mainly as component of sulfide ores of copper. As mentioned, Tl is present in wastewaters at this place. However, mining companies often do not want their $\mathrm{Tl}$ concentrations values be published. Water concentrations of $1-80 \mathrm{ppb}$ have been reported for rivers draining metal mining areas. It has been suggested that $\mathrm{Tl}$ in mining districts is transported in waters mainly as sulfates, arsenates and chloride complexes ${ }^{39}$.

On the contrary, the lowest $\mathrm{Tl}$ concentration was found in Puente Posada; three times lower than in La Cascada and twice lower than in Coya Sur and Yalquincha. In these sampling places the thallium input from the ground water via roots is similar to that observed for the stems and leaves.

Concentration of $\mathrm{Tl}$ in Tessaria absinthioides and those reported for some heavy metals in the same plants $(\mathrm{Cd}, \mathrm{Pb}, \mathrm{Co} \text { and } \mathrm{Ni})^{32}$ can be compared (Fig.4). The element pattern indicates that this plant accumulates much more $\mathrm{Cd}, \mathrm{Co}, \mathrm{Pb}$ and $\mathrm{Ni}$ than $\mathrm{Tl}$. Cadmiun concentration in leaves $>$ stems $>$ roots in all sites collected. In opposition, $\mathrm{Pb}$ (exception made of $\mathrm{La}$ Cascada close to anthropogenic sources of heavy metals) and $\mathrm{Ni}$ concentrations in roots $>$ leaves $>$ stems. Thus, roots are the best bioaccumulator for for $\mathrm{Tl}, \mathrm{Pb}$ and $\mathrm{Ni}$, while, in most cases, leaves are the best accumulator for $\mathrm{Cd}$ and $\mathrm{Co}$.

Lead is generally of limited mobility in plants and is mostly found in roots, while $\mathrm{Cd}$ is well known to be relatively mobile in plants. The differences in the bioaccumulation of $\mathrm{Tl}$ and the heavy metals, however, suggest that the mode of action within the body probably also differs between these metals.

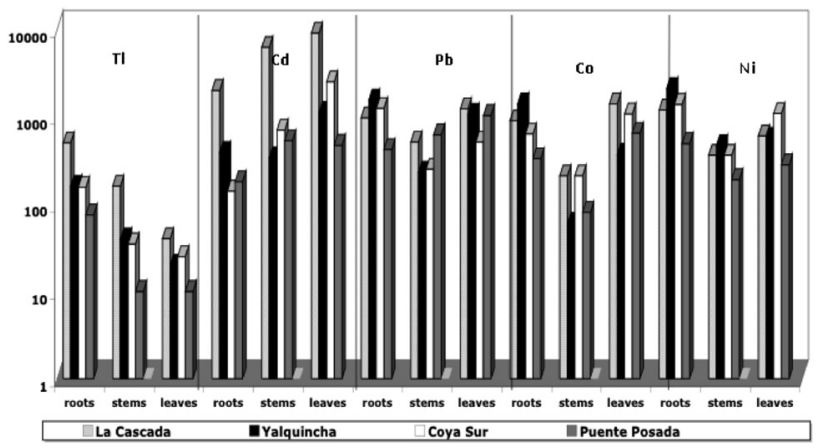

Figure 4. $\mathrm{Tl}, \mathrm{Cd}, \mathrm{Pb}, \mathrm{Co}$ and $\mathrm{Ni}$ levels (ngg-1 dry wt.) in different parts of Tessaria absinthioides collected at the River Loa basin. 
Thallium bioaccumulation in algae.

Table 6 shows $\mathrm{Tl}$ concentration in two algae. Values for $\mathrm{As}$ and $\mathrm{Cu}$ reported in previous works ${ }^{33}$ are also shown for comparison. The very high thallium concentrations found in all sampling areas corroborate the high pollution level of natural waters near to the smelter. The results show also that the species studied have wide tolerance ranges for Tl. Observed ranges are from 0.295 to $8.30 \mu \mathrm{gg}^{-1}$ d.w in Myriophyllum acuaticum and from 0.615 to $7.34 \mu \mathrm{gg}^{-1}$ d.w in Zannichelia palustris. These values indicate that the mining activity can be responsible for the distribution of high $\mathrm{Tl}$ concentrations in algae at La Cascada and Yalquincha. Moss and algae samples from Canada water that receives mining operation effluents contain $\mathrm{Tl}$ in concentrations ranging from 9.5 to $162 \mu \mathrm{gg}^{-1}$ dry weight ${ }^{1}$. Our study shows that the $\mathrm{Tl}$ values we found were lower and reflect an elevated pollution in Canada.

Samples obtained from river Salado (it originates at the El Tatio geysers, having extremely hot water reaching $86^{\circ} \mathrm{C}$ ) showed the highest levels of $\mathrm{Tl}$. It can be concluded that $\mathrm{Tl}$ from water bioconcentrates in the tissues of the aquatic plants. This implies that $\mathrm{Tl}$ accumulation in algae increases with time throughout the growth process.

Table 6. Some trace element concentrations ( $\mu$ gg-1 d.w. \pm SD)* in Zannichelia palustris and Myriophyllum acuaticum collected at the River Loa basin.

\begin{tabular}{|l|l|c|c|c|}
\hline \multirow{2}{*}{ Sampling area } & \multicolumn{1}{|c|}{ Algae } & Tl & As & Cu \\
\hline \multirow{2}{*}{ La Cascada } & $\begin{array}{l}\text { Zannichelia } \\
\text { palustris }\end{array}$ & $7.34(0.02)$ & $810(10)$ & $12.5(0.1)$ \\
\hline Yalquincha & $\begin{array}{l}\text { Zannichelia } \\
\text { palustris }\end{array}$ & $\begin{array}{c}0.615 \\
(0.055)\end{array}$ & $498(8)$ & $43.2(0.6)$ \\
\cline { 2 - 5 } & $\begin{array}{l}\text { Myriophyllum } \\
\text { acuaticum }\end{array}$ & $6.27(0.06)$ & $707(4)$ & $20.9(0)$ \\
\hline Ayquina & $\begin{array}{l}\text { Myriophyllum } \\
\text { acuaticum }\end{array}$ & $\begin{array}{c}0.295 \\
(0.005)\end{array}$ & $89(7)$ & $117(7)$ \\
\hline $\begin{array}{l}\text { Salado river } \\
\text { (at Yerbas } \\
\text { Buenas) }\end{array}$ & $\begin{array}{l}\text { Myriophyllum } \\
\text { acuaticum }\end{array}$ & $8.30(0.05)$ & $900(11)$ & $36(1)$ \\
\hline
\end{tabular}

*Mean of three independent determinations.

Coefficients of variation (CV) for Tl and for As were less than $8 \%, \mathrm{CV}$ for $\mathrm{Cu}$ determination was less than $6 \%$.

As seen, the other two important toxic elements of interest, $\mathrm{Cu}$ and As, show also high contents in both algae, being higher than Tl level. According to this observation, the aquatic system under study shows clear signs of $\mathrm{Cu}$ and $\mathrm{As}$ pollution and suggests a real impact of the mining activity over the Loa basin.

\section{Thallium levels in water}

Water samples at all sampling sites were characterized in the field by determining $\mathrm{pH}$, temperature, conductivity and $\mathrm{O}_{2}$ concentration. All collected physico-chemical parameters and $\mathrm{Tl}$ and $\mathrm{Pb}$ concentrations in surface water samples are presented in Table 7. Overall, surface water shows near neutral to alkaline $\mathrm{pH}$, values ranging from 6.93 to 8.56 . According to the $\mathrm{O}_{2}$ concentration $(3.55-11.8 \mathrm{mg} / \mathrm{L})$ and the wide range of total dissolved solids (TDS: 0.23 $4.84 \mathrm{~g} / \mathrm{L}$ ), the water in the upper Loa (Toconce, Lequena and Quinchamale) has a relative low TDS while the sampling site La Cascada shows a relative high pollution.
Table 7. Physico- chemical parameters and some trace element concentrations of surface waters from the Rio Loa basin.

\begin{tabular}{|l|c|c|c|c|c|c|c|}
\hline River & $\mathrm{pH}$ & $\begin{array}{c}\mathrm{T}^{\circ} \mathrm{C} \\
(\text { water }\end{array}$ & $\begin{array}{c}\text { Conductivity } \\
{[\mathrm{mS} / \mathrm{cm}]}\end{array}$ & $\begin{array}{c}\mathrm{O}_{2} \\
{[\mathrm{ppm}]}\end{array}$ & $\begin{array}{c}\mathrm{TDS} * \\
{[\mathrm{~g} / \mathrm{L}]}\end{array}$ & $\begin{array}{c}\mathrm{Tl} * * \\
{[\mathrm{ng} /} \\
\mathrm{ml}]\end{array}$ & $\begin{array}{c}\mathrm{Pb}^{* *} \\
{[\mathrm{ng} / \mathrm{ml}]}\end{array}$ \\
\hline Toconce & 7.63 & 6.7 & 1.19 & 6.04 & 0.23 & 0.012 & 0.26 \\
\hline Lequena & 8.56 & 7 & 1.06 & 11.3 & 0.55 & 0.006 & 0.08 \\
\hline Quinchamale & 8.19 & 13 & 1.77 & 11.8 & 0.83 & 0.014 & 0.23 \\
\hline Ayquina & 6.93 & 18 & 1.74 & 3.81 & 1.65 & 0.021 & 0.17 \\
\hline Rio Salado & 7.61 & 9 & 4.96 & 3.65 & 3.12 & 0.005 & 0.06 \\
\hline Yalquincha & 7.96 & 6 & 4.12 & 8.78 & 3.29 & 0.076 & 1.2 \\
\hline La Cascada & 8.23 & 11 & 4.68 & 3.55 & 4.84 & 0.12 & 2.4 \\
\hline Coya Sur & 7.87 & 6 & 4.66 & 6.7 & 2.53 & 0.011 & 0.05 \\
\hline Puente Posada & 7.90 & 8 & 3.56 & 5.82 & 1.82 & 0.003 & 0.03 \\
\hline
\end{tabular}

$*$ TDS $=$ Total disolved solids

**Mesurements done by ICP-MS

The hot spring water from El Tatio (temperatures close to $90^{\circ} \mathrm{C}$, TDS 2.5 $-9.8 \mathrm{~g} / \mathrm{L}$ and As $25 \mathrm{mg} / \mathrm{L}$ ) is the source of the Rio Salado (Fig 1) which explains the high TDS value However, downstream near the medium Loa basin the increase of TDS (Yalquincha $3.29 \mathrm{~g} / \mathrm{L}$ and La Cascada $4.84 \mathrm{~g} / \mathrm{L}$ ) is related to pollution.

Results obtained in our study show that dissolved thallium concentrations in the salt rivers average 3-120 $\mathrm{ng} / \mathrm{L}$. As can be expected, at La Cascada, the nearest sampling site to Calama city, an elevated concentration of $\mathrm{Tl}$ and $\mathrm{Pb}$ was observed. In general, Tl levels declined downstream except in La Cascada where inputs from several industries presumably occasioned the observed elevated concentrations. The presence of $\mathrm{Tl}$ in water clearly diminishes with increasing distance from the source, particularly at the surroundings of the Chuquicamata smelter.

Cheam et $\mathrm{al}^{38}$ reported that dissolved $\mathrm{Tl}$ concentrations average $5-10 \mathrm{ngL}^{-1}$ in unpolluted and 20-50 $\mathrm{ngL}^{-1}$ in polluted freshwater, but Zitko indicated that the concentrations of $\mathrm{Tl}$ in river water receiving mining operation effluents ranged from $0.7 \mu \mathrm{gL}^{-1}$ to $80 \mu \mathrm{gL}^{-1}$ at locations in Canada.

There is a need of developing treatment technologies to reduce $\mathrm{Tl}$ levels in mine effluents and ground impacted water. The very dry climate in northern Chile favors strong evaporation and the lack of raining does not allow dilution.

\section{CONCLUSIONS}

In summary, found $\mathrm{Tl}$ concentrations in north Chile are low and quite comparable with concentrations at others parts of the world. Nevertheless, the presence of high concentrations of $\mathrm{Tl}$ in some environmental samples suggests an impact of the mining activity over the region. On another side, the high concentration values determined in potatoes far from the pollution source suggest as highly probable that potatoes pollution is more related to volcanic activity or to geochemical origin. The enrichment of $\mathrm{Tl}$ in vegetables and plants is closely related to the concentrations of $\mathrm{Tl}$ in soils. This study also points strongly to the conclusion that efficient bioaccumulators of Tl like potatoes should not be planted in areas of Tl-rich soils such as Talabre and Yerbas Buenas. Study on the health impact of Tl over the population exposed is needed and the removal of $\mathrm{Tl}$ from waters and wastewaters should be investigated.

The GFAAS approach to the determination of $\mathrm{Tl}$ in environmental samples after wet digestion is a very reliable, sensitive and accurate method.

\section{ACKNOWLEDGEMENTS}

The financial support of the Universidad Católica del Norte, Chile, and BMBF-Germany and of the International Bureau of Research Centre Jülich, Germany, is gratefully acknowledged. We also thank Frau Mechthil Burow from the Laboratory of the FZ-Juelich, for crosschecking results for Tl with ICP-MS. Wir thanks to Professor Julio Pastenes, M.Sc. in Biology, from the Department of Biosciences at the University of Antofagasta. 


\section{REFERENCES}

1. V. Zitko, Toxicity and pollution potential of thallium. The Science of the Total Environment, 4, 185 (1975)

2. J.P. Mulkey and F.W. Oehme, A rewiu of thallium toxicity. Vet. Human Toxicol. 35 (5), 445 (1993)

3. P.W. Pau, Management of thallium poisoning. Hong Kong Medical Journal, 6 (3), 316 (2000)

4. J. Atsmon, E. Taliansky, M. Landau, M.Y. Neufeld, Thallium poisoning in Israel. The American Journal of the Medical Sciences, 320 (5), 327 (2000)

5. J. Oehlmann and B. Markert, Human Toxicology. WVG - Stuttgart, 131 (1997)

6. A.L. Peter, T. Viraraghavan, Thallium: A review of public health and environmental concerns. Environ. Int., 31, 493 (2005).

7. T. Stafilov and K. Cundeva, Talanta, 46, 1321 (1998)

8. K. Robinson, in: U.S. Mineral Resources, Geological Survey, (Ed) D.A. Brobst and W.P. Pratt, Professional Paper 820; U.S. Government Printing Office, Washington, 631 (1973)

9. G.P. Glasby, Marine Chem., 1, 105 (1973)

10. S. Galván-Arzate, A. Santamaría, Thallium Toxicity. Toxicology Letters 99, 1 (1998)

11. S. Moeschlin, Thallium poisoning. Clin. Toxicol. 17 (1), 133 (1980)

12. J.A. Arruda and M.A. Torres, Hospital, 77 (6), 1971 (1970)

13. R. Guerra, H. Martínez and H.J. Villarreal, Revista de Investigación Clínica, 32 (4), 381 (1980)

14. R. Rangel-Guerra, H. R. Martínez and H.J. Villarreal, Gaceta Médica de México, 126 (6), 487 (1990)

15. A. Cabanillas, F. Diéz, A. Sanz, P. Saenz de Arazubia, Anales de Medicina Interna, 6 (12), 658 (1989)

16. E. Altuna, J. Martí, J. E. Azparren, J.M. Bustillo, Revista Clínica Española, 186 (7), 362 (1990)

17. J. Huang, J. Wei. S. Li, Thallium poisoning a clinical analysis of 5 cases, Zhonghua Yi Xue Za Zhi, 78 (8), 610 (1998)

18. I. Tromme, D. Van Neste, F. Dobbelaere, B. Bouffioux, C. Courtin, T. Dugernier, M. Dupuis, Skin signs in the diagnose of thallium poisoning. The British Journal of Dermatology, 138 (2), 321 (1998)

19. D.E. Rusyniak, R.B. Furbee, A. Mark, Thallium and arsenic poisoning in a small midwestern town. Annals of Emergency Medicine, 39 (3), 307 (2002)

20. J. Cordero, P. Olivos, Acute thallium poisoning. Revista Chilena de Pediatria, 47 (5-6), 373 (1976)

21. M. Hirata, K. Taoda, M. Ono-Ogasawara, M. Takaya, N. Hisanaga, A probable case of chronic occupational thallium poisoning in a glass factory. Industrial Health, 36 (3), 300 (1998)

22. H. Aoyama, M. Yoshida, Y. Yamamura, Toxicology, 53, 11 (1988)

23. G. Repetto, A. del Peso, M. Repetto, Human thallium toxicity, in: Thallium in the Environment, (ed) Nriagu J.O., Wiley, New York, 167 (1998)

24. A. Brockhaus, R. Dolgner, U. Ewers, U. Kraemer, H. Soddemann, H. Wiegand, International Archives of Occupational and Environmental Health, 48 (4), 375 (1981)

25. U. Ewers, Environmental exposure to thallium, The Science of the Total Environment, 71 (3), 285 (1988)
26. F. Kemper, H.P. Bertram, Thallium, in: Metals and Their Compounds in the Environment, (ed) Merian E., VCH Verlagsgesellchafts $\mathrm{mbH}$, Weinheim, II (29), 1227 (1991)

27. M.A. Allus, R.G. Brereton and G. Nickless, The effect of metals on the growth of plants: the use of experimental design and response surfaces in a study of the influence of $\mathrm{Tl}, \mathrm{Cd}, \mathrm{Zn}, \mathrm{Fe}$ and $\mathrm{Pb}$ on Barley Seedlings, Chemometrics and Intelligent Laboratory Systems, 3, 215 (1988)

28. Anuario Metereológico. Publicación de la Dirección Metereológica de Chile (DMC). Dirección de Aeronaútica Civil, Santiago, Chile, (2005)

29. F. Queirolo, S. Stegen, M. Schwuger, P. Ostapczuk, Research on Anthropogenic and Natural Contamination Sources in Northern Chile, Inernational Cooperation Scientific Series of the International Buero, Forschungszentrum Juelich GmbH, Central Library, Vol. 44, (2000)

30. F. Queirolo, S. Stegen, M. Restovic, M. Paz, P. Ostapczuk, M.J. Schwuger, L.Muñoz. Total arsenic, lead and cadmium levels in vegetables cultivated at the Andean villages of northern Chile. The Science of the Total Environment 255, 85 (2000)

31. F. Queirolo, S. Stegen, J. Mondaca, R. Cortes, R. Rojas, C. Contreras, L. Muñoz, M.J. Schwuger, P.Ostapczuk. Total arsenic, lead, cadmium, copper and zinc in some salt rivers in the northern Andes of Antofagasta, Chile. The Science of Total Environment, 255, 75 (2000)

32. S. Stegen; F. Queirolo, Y. Contador; J. Pastenes; P. Ostapczuk; F. Backhaus. Tessaria absinthioides: a possible bio-monitor for $\mathrm{Cd}, \mathrm{Pb}$ and $\mathrm{Cu}$ in the middle and lower basin of the Loa River, north Chile. Toxicological and Environmental Chemistry, 77, pp.107 (2000)

33. S. Stegen; F. Queirolo, S. Cortés; J. Pastenes; P. Ostapczuk; F. Backhaus, C. Mohl. Use of Fresh Water Plants Zannichellia palustris and Myriophyllum acuatium for Biomonitoring of $\mathrm{Cd}, \mathrm{Pb}$, and $\mathrm{Cu}$ in Anden Rivers of Chile., Bol. Soc. Chil. Quim. 45, 449 (2000)

34. S. Stegen., F. Queirolo, C. Carrasco, Peter Ostapczuk and Milan Schwuger. "Concentration of Ni and Co in Crop Plants Cultivated in Northern Chile". Bol. Soc. Chil. Quim., 47, 279 (2002).

35. S. Stegen, F. Queirolo, F. Vinagre, P. Ostapczuk, A. Groemping, M. Paz, M. Restovic, C. Carrasco, Comparison of different methods for the determination of the water content and the dry mass correction factor in various plant samples, Fresenius J Anal Chem, 360, 601 (1998)

36. www.mckinley.uiuc.edu/Handouts/vitaminmineral.html

37. Z. Zhang, B. Zhang, J. Long, X. Zhang, G. Chen, Thallium pollution associated with mining of thallium deposit. Sci. China, Ser D; 41(1), 75 (1998)

38. V. Cheam, Thallium contamination of water in Canada. Water Qual Res $J$ Can 36, (4): 851 (2001).

39. L. Gildhagen, H. Kahelin, P. Schmidt-Thome, C. Johansson, Anthropogenic and natural levels of arsenic in PM 10 in central and northern Chile. Atmospheric Environment 36, 3803 (2002).

40. RAIS (Risk Assessment Information System). Toxicity Profiles. Available from: www.rais.ornl.gov/tox/profiles

41. T. Xiao, J. Guha, C. - Q. Liu, B. Zheng, G. Wilson, Z. Ning, L. He, Potential health risk in areas of high natural concentrations of thallium and importance of urine screening. Applied Geochemistry 22, 919 (2007).

42. C.E. Hanzel and S.V. Verstraeten, $\mathrm{Tl}(\mathrm{I})$ and $\mathrm{Tl}(\mathrm{III})$ activate both mitochondrial and extrinsic pathways of apoptosis in rat pheochromocytoma (PC12) cells. Toxicological and Applied Pharmacology, 236, 59 (2009). 